\title{
Rethinking investment dynamics: An alternative framework of the global land rush
}

\author{
Elizabeth Starr* \\ Washington, D.C.
}

\begin{abstract}
Submitted May 22, 2013 / Revised August 10, 2013; December 11, 2013; and December 18, 2013 /
Published online January 28, 2014

Citation: Starr, E. (2013). Rethinking investment dynamics: An alternative framework of the

global land rush. Journal of Agriculture, Food Systems, and Community Development, 4(1), 79-98.

http://dx.doi.org/10.5304/jafscd.2014.041.012

Copyright (C) 2014 by New Leaf Associates, Inc.
\end{abstract}

\begin{abstract}
Despite growing interest in "land grabbing," the comparative literature remains biased in several key ways, failing to capture the full diversity of land investments and to incorporate the important findings made by case-study researchers. This paper analyzes in particular three analytical blind spots in current typologies of the global land grab phenomenon: (a) the failure to incorporate nonproductive investments, including speculation; (b) the misguided focus on investor nationality, as opposed to capital flows; and (c) the tendency to ignore how domestic actors shape the terms of a land deal. In drawing attention to these limitations, this paper constructs two typologies of land investment - one describing physical changes in land use, and another mapping interactions between investors and developing country actors. Working in conjunction, they help to explain why land deals occur where they do and how they change not only

* Elizabeth Starr, Yale University, New Haven, Connecticut, USA.

The author is currently a researcher at the Universidad Nacional de Colombia. She can be contacted at Elizabeth.h.starr@gmail.com
\end{abstract}

the land itself, but also people's relation to the land. This paper therefore calls for a more nuanced analysis of the bargaining processes that underlie every land deal and also of the potential policy alternatives that may attract investment without sacrificing the livelihoods or lands of vulnerable local populations.

\section{Keywords}

capital flows, civil society, foreign capital, investors, land, land deal, land grab, speculation, typology

\section{Introduction}

Beginning in the mid-2000s, foreign investors started acquiring "undercultivated" agricultural lands across Africa, Asia, Latin America, and the former Soviet Union (Anseeuw, Boche, Breu, Giger, Lay, Messerli, \& Nolte, 2012; Hall, 2011). In regions like Africa, where only $2-10$ percent of land is formally tenured (Deininger, 2003), this socalled "global land grab" has had devastating

\footnotetext{
${ }^{1}$ The term "land grab" is in itself controversial. As Borras, Hall, Scoones, White, \& Wolford (2011) point out, it has become a "catch-all" for a wide variety of phenomena. The
} 
consequences for the local communities that live off land not formally belonging to them. Land acquisitions often generate higher local food prices, create fewer jobs than advertised, expel people from ancestral lands, destroy habitats, exacerbate ongoing land disputes, and disproportionately affect vulnerable populations, including women (Anseeuw, Alden Wily, Cotula, \& Taylor, 2011; Berhman, Meinzen-Dick, \& Quisumbing, 2011; Daley, 2011; Deininger, \& Byerlee, 2011b).

Much of this initial investment was in agricultural land, spurred by the growing food insecurity problems of powerful foreign states like the Gulf States and China after the food price crisis of 2008 (GRAIN, 2008). Mineral, water, and forest resources have also been affected (Zoomers, 2010). Many projects are designated for biofuels production, with roughly 40 percent of investors turning to "flex crops" that can be used as either food or fuel (Anseeuw et al., 2012). The term global land grab also obscures the role played by water, as large-scale agriculture often competes with and intensifies existing demand for water, sometimes generating social conflict (Anseeuw et al., 2012; Kay \& Franco, 2012; Woodhouse, 2012; Woodhouse \& Ganho, 2011).

Foreign investors frequently obtain long-term leases of up to 99 years from local governments (Cotula, 2011), although private purchases and conservation acquisitions are also common. Often plagued by corruption, these deals rarely compensate local populations for the resulting loss of access to resources (Vermeulen \& Cotula, 2010a).

Estimates for the total scale of these land acquisitions vary dramatically, ranging from 45 million hectares (111 million acres) (Deininger, \& Byerlee, 2011b) to over 200 million hectares (494 million acres) (Geary, 2012). Though difficult to quantify (Cotula, 2012), this scramble for land is likely here to stay. Food production must double by 2050 to meet growing global food needs, and much of this increased production will need to

word is highly politicized and may not give investors credit where it is due. For these reasons, I prefer to talk about the "global land rush" or "large-scale land acquisitions in developing countries," although I will occasionally use the word "land grab" for clarity. occur in developing countries (Food and Agriculture Organization of the United Nations [FAO], International Fund for Agricultural Development [IFAD], United Nations Conference on Trade and Development [UNCTAD], and the World Bank Group, 2008, cited in Borras \& Franco, 2010a). In monetary terms, this means US $\$ 80$ billion of investment per year (Blumenthal, 2012). Large-scale agriculture provides one avenue to meet this demand, but more inclusive business models also exist, including contract farming, leases and management contracts, tenant farming, and farmerowned businesses (Vermeulen \& Cotula, 2010b).

Moreoever, the recent land rush is distinct from other, earlier instances of neo-imperial influence. These new investments have attracted new types of investors - especially investors with little experience in agriculture - and are refocusing on countries with weak governance, many of which received little foreign investment until the 1990s (Cotula, Vermeulen, Leonard, \& Keeley, 2009; Deininger, \& Byerlee, 2011b). Furthermore, these deals share an immediate trigger - the foodprice crisis of 2007-2008 — although long-term price expectations, population growth, and resource demand will likely sustain it over the long term (Anseeuw et al., 2011).

Although our knowledge of this land rush has deepened considerably since 2008 , there is still much to learn. This paper focuses on transnational land deals (excluding purely domestic ones) and notes three limitations in current comparative research: (a) the lack of attention paid to nonproductive investments, including speculation; (b) the failure to examine capital flows and how foreign investors may be involved indirectly in "domestic" projects; and (c) the tendency to ignore why and how local governments and civil society organizations may attract, condone, or oppose such investments. Although individual case studies have dealt with some of these issues, especially the role of domestic actors, there has been little comparative work, on either a regional or global level, that addresses these three factors.

To what extent have these omissions in the comparative academic literature biased the extant research agenda? To get at this question, I propose two new typologies that map the interactions 
between investors and domestic actors, as well as describe changes in land use. These typologies are necessarily simplifications and are no substitute for rigorous case-study analysis. Rather, they allow for primitive accounting of known land deals and suggest new dimensions that may have been overlooked in previous investigation. In this way, these typologies have the potential to reveal undiscovered patterns in the terms of land purchases or leases, to call for increased research on capital flows, and to restore agency and accountability to oft-overlooked domestic actors.

This paper proceeds as follows. First, I analyze existing comparative models of land rush, namely typologies, showing how they have advanced our knowledge of land investment and also how they have fallen short. I then present two typologies of land investment, which together describe the changes in land use and investor-domestic actor interactions. These typologies are then used to analyze two case studies: the paper pulp industry in Brazil and sugar cane ethanol in the Philippines. Finally, I conclude by discussing the economic, political, and ethical issues highlighted by this analysis. This shift in perspective not only reveals analytical blind spots in the current land research agenda, but it also raises important questions about how we should define justice - and by extension, injustice — in the land-grab debate, calling for a more nuanced understanding of what truly constitutes a "grab."

\section{A Model That Falls Short}

The comparative academic literature on the global land grab has come a long way since researchers began studying the phenomenon in earnest in 2008. Many early assumptions - for example, that food insecurity alone drove the investment - have since been relaxed or discredited. There has been a proliferation of thoughtful case-study analysis, as well as increased investigation into green grabbing, water grabbing, and other non-agricultural land purchases. Nevertheless, despite this wealth of case-study knowledge, the comparative literature on land grab, especially existing typologies, remains insufficient, often failing to incorporate the diverse and at times contradictory discoveries made by empirical researchers.
This paper attempts to bring global models of land grab up to date by analyzing a wealth of casestudy research, in addition to highlighting where case-study analysis itself could be improved. In this section, I address a handful of limitations of current land-grab frameworks.

First, in comparative studies of land grab, causal explanations have focused almost exclusively on market demand. The prevailing model claims that rising food and fuel prices have made food and energy security a vital concern for many states, prompting increased foreign investment in agricultural lands in the developing world. Despite the evidence for growing demand for such "underdeveloped" land, host countries also play an important role in attracting or at least permitting foreign investment in agricultural land (see, for example, Clancy, Lovett, \& Marin, 2011, on Colombian biofuels; MacInnes, 2012, on corruption; Woods, 2013, on Burma's emerging "agro-industrial complex"). What do local states have to gain from selling underdeveloped land? How do domestic elites shape land politics? Such questions are common in the discussion of specific land deals, but they are often lost in more comparative, global models of the land rush.

Second, academics, journalists, and policymakers have overemphasized African cases. The most egregious violations of land rights do occur in Africa, home to anywhere between 62 (Anseeuw et al., 2012) and 70 percent of land acquisitions (Deininger, \& Byerlee, 2011b). Nevertheless, this process is occurring elsewhere (in Latin America, Southeast Asia, and Eastern Europe) under very different conditions (Baquero \& Gómez, 2012; Borras, Franco, Gómez, Kay, \& Spoor 2012; Wolford, 2010a). In order to adequately assess the scope of the global land rush, we first need to document and analyze the full spectrum of variation, not just the types of deals occurring in Africa.

Third, there is little to no aggregate information about who is investing, where they are obtaining land, and at what cost. Many recipient countries lack land registries and some companies obscure this information, making such research logistically difficult (Cotula et al., 2009). Even so, the focus has been on foreign "investors," as defined by their nationality. Source of capital, however, is the more important distinc- 
tion between investors, since international firms or intergovernmental investors sometimes fund socalled "domestic investors."

Fourth, speculative land investment is rarely, if ever, studied as a phenomenon unto itself although it is probably rampant. Many agrarian researchers assume that purchased land is ultimately put to some productive use, but some investors are in fact buying land for the relative security and high returns of the investment, as compared to other, more traditional asset classes (De Schutter, 2010; Geary, 2012; Liu, Koroma, Arias, \& Hallam, 2013; Deininger, \& Byerlee, 2011b). To date, only 21 to 27 percent of land deals have led to any "implementation activity" or production, with the rest remaining idle (Anseeuw et al., 2012; Deininger, \& Byerlee, 2011b). Although some of these tracts will eventually see agricultural production, this cultivation may not happen in the near term, and in the interim, local farmers are often denied access, inhibiting their own farming (Hinshaw, 2011).

In light of these biases in the comparative literature, we are in need of an alternative framework that better captures the full variation of land deals. In this paper, I propose a new typology that maps the interactions between investors and recipient country actors, thereby underscoring the bargaining processes that lead to a land deal, be they advantageous or detrimental to local interests. In addition to this interactions typology, I amend an earlier typology by Hall (2011) to incorporate nonproductive and speculative investments, which may account for up to three-quarters of all land projects. Through careful variable selection, these typologies shed light on underlying patterns in land investment that are particularly noteworthy or have been hitherto ignored by comparative researchers.

\section{Why Typologies?}

As an analytic tool, typologies allow us to draw comparisons between existing cases and make predictions about unknown ones based on combinations of a given set of variables. Typologies only focus on a small number of variables, out of a wide variety of potential candidates. Such variables could include land use change, type of investor, extent of land cultivation, business model of the incoming company, amount of "available" land nationwide, and more.

With the "right" variable selection, a typology reveals fundamental causal configurations. That is, it not only answers the questions of who, where, when, and how, but also gets at why a given outcome occurred. A well-defined typology balances the competing goals of explanatory power and simplicity and can make sense of a complex phenomenon without ignoring variation.

Perhaps the most important feature of a typology is the so-called "empty case." In any typology, some categories will be more common than others, and some will appear to be empty - that is, some variable combinations may, seemingly, not exist. Do these empty cases represent theoretically impossible combinations, or instead, are they a gap in our knowledge that must be filled? In this way, a typology not only highlights what has been understudied by land-grab researchers, but also reveals which variables, which sets of circumstances, are correlated with the absence of land grab.

What a typology cannot do is provide detailed information about case studies or tell us much about the variables it overlooks (which will always be many). Where typologies can inform future case-study research is by highlighting important variables, suggesting combinations worth investigating, and allowing cross-case comparison between similar "types." In the end, the following typologies will raise more questions than they can possibly answer. My hope, then, is that those questions may correct misconceptions in the comparative literature to date and lead to more thoughtful, more targeted research in the future.

\section{Analyzing Existing Typologies}

Borras and Franco (2010a), Deininger and Byerlee (2011), and Hall (2011) are among a handful of authors who have built typologies of land deals, providing a solid foundation for the new framework presented in this work. These existing typologies overcome one flawed assumption of the early reports on land grab, which is that it only represents a transition from small-scale to largescale agriculture. Moreover, they acknowledge that not all land deals fit neatly into the "food security" discourse promoted by early researchers. Nevertheless, these typologies fall short because they (a) do 
not account for speculative and nonproductive investments, (b) ignore how foreign capital may fuel domestic agricultural investment, and (c) downplay the bargaining processes that take place between investors and host countries, which are already well documented for some case studies.

\section{Typologies by Agrarian Researchers}

Building upon Borras and Franco (2010a), Hall (2011) develops a typology of land use change, divided into six types (figure 1).

In Type A (food to food), the land is still used for food production, but this production may have intensified and its goals may have shifted, perhaps from domestic exchange to food production for export. In Type B (food to biofuels), land that was formerly used for food production or to feed the local population has been converted to biofuels production with the hope of meeting rising energy needs. Type C (food to nonfood) often involves displacing local communities in order to carry out mining or tourism projects, whereas in Type $\mathrm{F}$ (nonfood to nonfood), "unused" land is converted into tree farms, mines, or ecotourism sites. Type D (nonfood to food) refers to land that was not primarily used for food production, but now is. Finally, Type E (nonfood to biofuels) refers to land that was formerly "unused" in some capacity and that is now targeted for biofuels production.

This typology's primary utility is that it allows for an accounting of the net change in land use. Since it operates at the level of individual projects, regardless of scale, we can tally different types and determine whether given regions, countries, or continents are experiencing more or less food production than before. In this way, the typology helps us to gauge the relative importance of food and energy insecurity as drivers of the land rush.
Still, this typology is imperfect because it combines both productive and nonproductive land use into the "nonfood" category. By nonproductive, I mean land that is not productive of food, fuel, or other natural resources. Taking tourism as an example, we see that such "nonproductive" land might still create jobs or income, but it neither produces nor extracts resources from the land, as would occur with other types of "nonfood" uses (e.g., forestry). This nonproduction would have distinct effects on the physical and social landscape, whether by preserving natural ecosystems or creating few agricultural jobs.

\section{Typology by the World Bank}

Representing another group of land-grab researchers, reports by the World Bank tout the need for foreign direct investment in developing countries as a way to boost productivity in the face of food security concerns. Although this framework does incorporate investor motivations, it too ignores the roles of host countries in attracting, condoning, or opposing foreign agricultural investment.

Deininger and Byerlee's (2011) typology epitomizes the World Bank perspective, focusing on two salient and measurable variables: the availability of uncultivated land and yield gaps. Here, a yield gap is the "difference between possible output and what is currently attained" and reflects "the extent to which gaps in technology, institutions, or other public goods (e.g. infrastructure) prevent existing cultivators from realizing there [sic] potential" (Deininger \& Byerlee, 2011a, p. 17).

As figure 2 illustrates, countries fall into types based on the relative availability of uncultivated land and their current yield gaps, with the types loosely corresponding to geographic regions.

Figure 1. Typology of Land Use Change, by Hall (2011)

\begin{tabular}{lccc}
\hline & To Food & To Biofuels & To Nonfood \\
\cline { 2 - 4 } From Food & $\begin{array}{c}\text { Type A } \\
\text { Food to Food }\end{array}$ & $\begin{array}{c}\text { Type B } \\
\text { Food to Biofuels }\end{array}$ & $\begin{array}{c}\text { Type C } \\
\text { Food to Nonfood }\end{array}$ \\
\hline From Nonfood & $\begin{array}{c}\text { Type D } \\
\text { Nonfood to Food }\end{array}$ & $\begin{array}{c}\text { Type E } \\
\text { Nonfood to Biofuels }\end{array}$ & $\begin{array}{c}\text { Type F } \\
\text { Nonfood to Nonfood }\end{array}$ \\
\hline
\end{tabular}

Hall, R. (2011). Land grabbing in Southern Africa: The many faces of the investor rush. Review of African Political Economy, 38(128), 193-214. http://dx.doi.org/10.1080/03056244.2011.582753 
Figure 2. Potential Land Availability vs. Yield Gap for Developing Countries

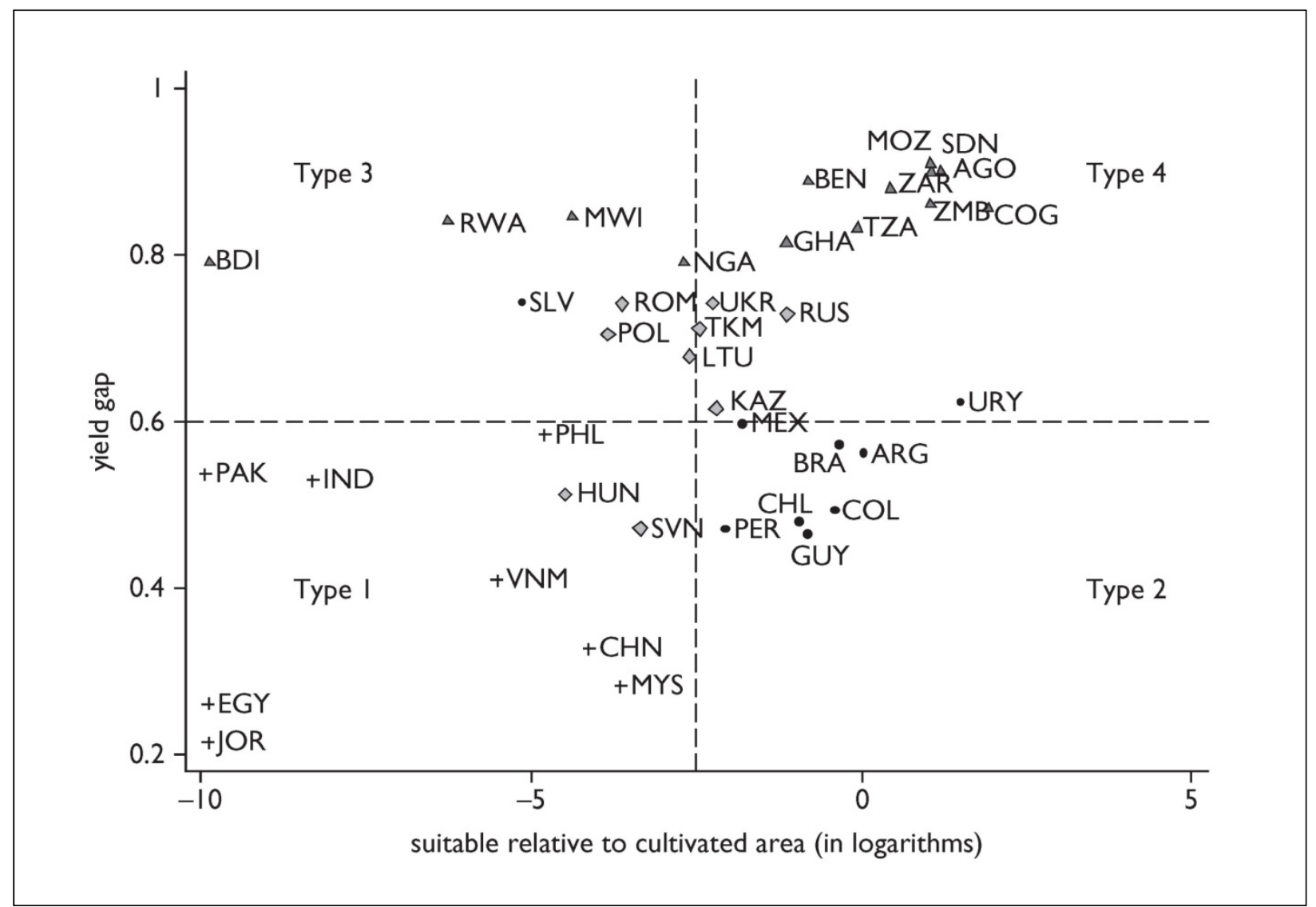

Note: Dashed lines indicate average yield gap and $50^{\text {th }}$ percentile for relative suitability.

Source: Deininger, K., \& Byerlee, D. (2011). Rising global interest in farmland: Can it yield sustainable and equitable benefits? [Based on Fisher \& Shah, 2010]. Washington, D.C.: World Bank. Used with permission of The World Bank.

Type 1, which represents low yield gaps and low availability (i.e., high population density), is found predominantly in Asian countries. Type 4 is at the other extreme, representing high quantities of available land and high yield gaps. In the land deals documented by the Land Matrix Project, a full 58 percent of land deals are Type 4, with many of these being in countries in sub-Saharan Africa (Anseeuw et al., 2012). Type 2 is found in several Latin American countries, which have lower yield gaps but still have large quantities of uncultivated land. Finally, Type 3 represents high yield gaps but low availability, which is the case for "most developing countries," according to Deininger and Byerlee (2011).

Unlike the typologies by Borras and Franco (2010a) and Hall (2011), this model only operates at the country level and cannot be applied to specific projects. As such, it loses much of the domestic variation that occurs across different provinces, different types of investors, and different industries. Moreover, the typology uses population density bright lines (e.g., 10 or 25 persons/sq. $\mathrm{km}$ ) and yield bright lines (60 percent of the potential yield for a crop) in order to determine land that would be "suitable" for cultivation. In this way, the framework ignores the thorny question of what land should really qualify as available and suitable. Population density says little about the extent of cultivation, since some crops are more land-intensive than others. Furthermore, any such bright line wholly ignores a variety of non-agricultural uses for land resources; for example, a tract of land may be a ritual or ceremonial site, provide access to other natural resources like water, or be used for hunting and 
gathering. Such lands would qualify as "suitable" for cultivation under this typology, even though it would be unpalatable to local communities.

\section{An Alternative Framework of Land Rush}

Even though these existing typologies cover a wide range of land deals, they remain imperfect. In the following sections, I construct a novel interactions typology that unpacks investor dynamics, including capital flows, and regulation by host countries. Compared to existing typological frameworks, this work constitutes a shift in perspective, since both investors and domestic actors are to blame when and if land deals harm local populations. In so doing, it restores agency to oft-ignored domestic actors, such as national and local governments and civil society organizations.

In the search for an alternative framework of land rush, I will also amend Hall's land use typology to deal with another bias of the existing literature: the dismissal of nonproductive investments, including conservation, tourism, and speculation. Although allowing for nonproduction is an improvement, this revised typology will remain insufficient to explain why land deals occur where they do, necessitating the creation of the interactions typology.

\section{Typology 1: Directions of Land Use Change}

First, in order to account for land that has transitioned to nonproduction, I add a fourth column to the land use change typologies by Borras and Franco (2010) and Hall (2011) to create a new typology (figure 3).

Type D (food to nonproduction) involves lands once devoted to agricultural production for food consumption, which are then transformed for nonproductive uses. "Nonproduction" here is a broad category for land that is no longer being cultivated or tapped for its natural resources. That is, there is no agricultural production for food or for biofuels, nor are other resources extracted, such as minerals or timber. This category thus captures several different trends: speculative investment, conservation, and ecotourism, to name a few.

In some cases, formerly cultivated land is taken out of production and investors let the lands sit idle, hoping to recuperate the original price (and then some) in a few years. These investors are unlikely to be driven by food-security concerns, but rather are capitalizing on the accompanying food price spikes in order to resell land and earn sizable returns on their investment.

For example, in 2008, the government of Mali gave 100,000 hectares (247,000 acres) of land for free to Muammar el-Qaddafi of Libya, conditional on ongoing agricultural investment (GRAIN, 2012). After the agreement, local farmers were forced off the land and their houses were leveled, but as of 2012 the land had still not seen agricultural production, neither before nor after the collapse of the Qaddafi regime (GRAIN, 2012; MacFarquhar, 2010). As is often the case, researchers may be unable to determine whether the investor's intentions were speculative, but the failure to initiate production within a few years is a good indication of nonproduction. Even in cases where infrastructure investment and production eventually begin, the interim period of nonproduction often has devastating consequences on the food security and livelihoods of local communities.

Meanwhile, Type $\mathrm{H}$ (nonfood to nonproduction) represents land settings that were not used primarily for food production in the past, but that are now "nonproductive." Importantly, "nonfood" is at times an amorphous category and may include

Figure 3. A New Typology of Land Use Change

\begin{tabular}{lcccc}
\hline & To Food & To Biofuels & $\begin{array}{c}\text { To Nonfood } \\
\text { (extractive industries) }\end{array}$ & To Nonproduction \\
\hline From Food & $\begin{array}{c}\text { Type A } \\
\text { Food to Food }\end{array}$ & $\begin{array}{c}\text { Type B } \\
\text { Food to Biofuels }\end{array}$ & $\begin{array}{c}\text { Type C } \\
\text { Food to Nonfood } \\
\text { (extractive industries) }\end{array}$ & $\begin{array}{c}\text { Type D } \\
\text { Food to } \\
\text { Nonproduction }\end{array}$ \\
\hline From Nonfood & $\begin{array}{c}\text { Type E } \\
\text { Nonfood to Food }\end{array}$ & Nonfood to Biofuels & $\begin{array}{c}\text { Type } \mathbf{~} \\
\text { (extractive industries) }\end{array}$ & $\begin{array}{c}\text { Type H } \\
\text { Nonfood to } \\
\text { Nonproduction }\end{array}$ \\
\hline
\end{tabular}


lands that are used for some food production, harvesting, ceremonial purposes, or other communal functions. That is, taking these lands out of production may still have tangible and real effects on local populations beyond the mere transfer of ownership.

For example, the proposed Greater Limpopo Transfrontier Park in Zimbabwe sits on the ancestral lands of the Chitsa people, where they have gravesites, perform initiation and circumcision ceremonies, and believe the spirits to reside (Scoones, Chaumba, Mavedzenge, \& Wolmer, 2012). Despite numerous attempts to evict them, the Chitsa community continued to fight for restitution of its ancestral lands, and in 2011 a deal was reached whereby the Chitsa community retained access to some of the lands in question, but would be strictly forbidden from poaching or grazing in the adjacent park (Scoones et al., 2012). This attempted eviction illustrates the need for careful definitions of "unused" land and the potential for conservation projects to have adverse effects on local communities.

\section{Why do both speculation and conservation} belong to the same category?

Some might object to assigning speculative land acquisitions and conservation to the same category. While speculative investment suggests foreign investors taking advantage of cheap resources abroad in order to turn a profit, conservation projects are often framed as socially and environmentally necessary, including those by organizations like the World Wildlife Fund and Conservation International (Kelly, 2011). In reality, these two seemingly disparate phenomena are similar in that they dispossess local populations of their access to land, putting a halt to agricultural production altogether (Benjaminsen \& Bryceson, 2012; Fairhead, Leach, \& Scoones, 2012).

Moreover, the resulting social and environmental effects are often similar across nonproductive cases. Like purely speculative investments, conservation projects fail to generate new jobs or even a labor reserve, instead appropriating lands for the physical spaces themselves (Li, 2009). Likewise, designating land for conservation may involve forcible expropriation of land, violent removal of people from the land, destruction of livelihoods, and/or restructuring of the labor sector (Fairhead et al., 2012). Neither speculation nor conservation will in itself generate the same resource depletion that characterizes food production, biofuels, and the extractive industries. Indeed, conservation and tourism projects may experience ongoing investment to preserve fragile, natural ecosystems. Although all of these similarities merit the single category of nonproduction, there is considerable within-category variation and engaging with subtypes (e.g., conservation, tourism, speculation, etc.) will better illuminate the unique risks and benefits of a given project.

\section{Typology 2: Interactions Between Investors and Domestic Political Economy}

The land use typology is still insufficient as a framework for land grab. First, it is best at explaining differences in the effects of various projects, illuminating how the changes engendered by land deals have lasting impacts on the local sociopolitical and environmental landscape. However, it does little to explain why land deals occur where they do and under what conditions. That is, it tells us very little about the bargaining processes underlying the land rush.

The comparative land-grab literature often fails to challenge the prevailing assumption that international investors take advantage of countries with weak governance in orchestrating land deals. This "victim-oppressor" interpretation of land grab overlooks the complex interactions that occur between national governments, local governments, civil society organizations, small-scale farmers, and the investors themselves, be they domestic or foreign. While weak governance may be behind many land deals, it is not a hard and fast rule.

I thus create a second typology with the goal of restoring agency — and therefore accountability — to domestic actors and differentiating between categories of foreign investors (figure 4). This typology recognizes the diversity of actors involved in a given land deal, as well as their implicit and explicit roles in shaping its terms. Where land deals result in unacceptably grave costs, the blame does not fall on the investors alone, but on a whole range of individuals and organizations that either 
turned a blind eye or actively pursued policies at the expense of local populations or the environment, and sometimes to their own personal benefit.

This typology has two variables: the nature of the investment and the nature of any land deal regulation. As such, not all categories will be equally exploitative, eventually creating a space for potentially just and beneficial land deals.

\section{Investor Type}

The first variable is the type of investor: a foreign public investor, foreign private investor, or mixed domestic-foreign investors. Each investor "type" considers not only the investor's nationality, but also whether the source of capital is foreign or domestic. Since this paper will focus on land grab as a globalized phenomenon, domestic investors with purely domestic capital are omitted from this typology. Such purely domestic investments are also distinct from their transnational counterparts, warranting their exclusion. First, they are governed, at least in principle, by only local and national laws. Second, they reflect intracountry power dynamics between elites and rural populations, as opposed to power and resource differentials across countries. Third, although states must compete to maintain local investment, this competition is distinct from the intense competition they face for foreign investment. Fourth, capital flows remain within the country, whereas foreign capital brings with it the hope (whether false or true) that it will spur development.

The first category of the typology, foreign public investment, includes all public-sector actors using public funds to acquire land, be they governments, sovereign wealth funds, or other state-owned companies. Although these investments have drawn considerable attention in the past, states are increasingly moving away from direct investment, preferring to minimize risk by investing in private companies, guaranteeing loans, and providing tax rebates or other forms of assistance (Liu et al., 2013). This category also blurs somewhat with foreign private investments (Cotula et al., 2009). For example, does a partially state-owned Chinese company behave more like a fully state-owned company or a private enterprise? When the son of Crown Prince Sultan bin Abdul Aziz of Saudi Arabia signs a lease for 105,000 hectares $(259,000$ acres) in South Sudan, is he acting as a private individual or an emissary of the state, and what exactly is the distinction (GRAIN, 2012)?

Foreign private investment makes up the bulk of agricultural investment (Land Matrix Project, n.d.). It may involve one foreign company investing on its own, or a partnership across several different foreign companies. It is important to note that private-sector acquisitions often involve significant assistance from home-country governments in the form of subsidies, soft loans, guarantees, and insurance to private companies pursuing land investment abroad (Cotula, 2011).

The most complicated category, mixed

Figure 4. A New Typology of Investor-Host Country Interactions

\begin{tabular}{|c|c|c|c|c|}
\hline & & \multicolumn{3}{|c|}{ REGULATION, IF ANY } \\
\hline & & Little to no regulation & $\begin{array}{l}\text { Government-enforced } \\
\text { regulation }\end{array}$ & Civil society regulation \\
\hline \multirow{3}{*}{ 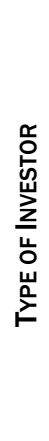 } & Foreign Public & $\begin{array}{c}\text { Type A } \\
\text { Foreign public } \\
\text { investment, little to no } \\
\text { regulation }\end{array}$ & $\begin{array}{c}\text { Type B } \\
\text { Foreign public investment, } \\
\text { government-enforced } \\
\text { regulation }\end{array}$ & $\begin{array}{c}\text { Type C } \\
\text { Foreign public } \\
\text { investment, civil society } \\
\text { regulation }\end{array}$ \\
\hline & Foreign Private & $\begin{array}{c}\text { Type } \mathbf{D} \\
\text { Foreign investor, little to } \\
\text { no regulation }\end{array}$ & $\begin{array}{c}\text { Type E } \\
\text { Foreign investor, } \\
\text { government-enforced } \\
\text { regulation }\end{array}$ & $\begin{array}{l}\quad \text { Type } \mathbf{F} \\
\text { Foreign investor, civil } \\
\text { society regulation }\end{array}$ \\
\hline & $\begin{array}{l}\text { Mixed (domestic } \\
\text { investor with foreign } \\
\text { capital or joint ventures) }\end{array}$ & $\begin{array}{c}\text { Type G } \\
\text { Mixed investor, little to } \\
\text { no regulation }\end{array}$ & $\begin{array}{c}\text { Type H } \\
\text { Mixed investor, government- } \\
\text { enforced regulation }\end{array}$ & $\begin{array}{l}\quad \text { Type J } \\
\text { Mixed investor, civil } \\
\text { society regulation }\end{array}$ \\
\hline
\end{tabular}


investment, encompasses all projects where there is at least some domestic ownership, funded at least in part by foreign capital. I further divide these investments into two categories: purely domestic investors with foreign capital, and joint ventures. In the first case, the entire project is owned by a domestic company or individual, but it receives significant funding from international or transnational sources. For example, most authors cite Peru as a case of purely domestic investment (Anseeuw et al., 2012; Deininger \& Byerlee, 2011a), despite the fact many projects receive significant foreign funding. Domestic investors - with or without foreign capital — account for the majority of land transactions worldwide, suggesting the need for closer analysis of capital flows in order to understand the transnational dimension of these so-called domestic acquisitions (Liu et al., 2013).

In the second case, several companies (some domestic, some foreign) jointly own, lease, or operate the project. Joint operations are especially common in countries that put limits on foreign land ownership, such as the Philippines (Borras, Franco et al., 2011). Unlike purely foreign investment, these joint partnerships tend to reduce administrative transaction costs (Anseeuw et al., 2012). Furthermore, domestic investors are better equipped to navigate local bureaucracy and engage corrupt officials, allowing for the faster settlement of a land deal (Deininger, \& Byerlee, 2011b).

Additionally, I draw attention to an oft-ignored distinction: the difference between foreign investors and foreign capital. The tendency is to talk about "foreign" and "domestic" investors, often ignoring how capital flows may make some domestic investors more similar to their foreign counterparts. I argue that capital is the more salient distinction, hence my inclusion of purely domestic investors with access to foreign capital. What enables land grab is developing countries' desire - and often need - for foreign funds to create growth. In competing for land deals, countries are often forced to make offers that sacrifice livelihoods or the environment for the sake of attracting additional funds. Capital alone is sufficient to create this pressure on states, and so it merits as much attention as the nationality of the investors themselves.

\section{Extent of Regulation}

The first category, little to no regulation, can be construed as the absence of any meaningful effort on the part of any actor to ensure that local populations and environments do not suffer adverse consequences under a land transfer, such as dispossession, reduced access to resources, environmental degradation, and destruction of livelihoods. Unfortunately, this is the de facto reality under which many land deals occur. Even in this category, there may still be some legal protections in place, but the spirit of the law is rarely if ever heeded. Likewise, there may be some activism on the part of rural social movements, but it is disorganized or weak.

In some cases, little to no regulation may entail governments actually seeking out and enabling international investment. Across the globe, governments have explicitly sought out "idle" lands with the goal of attracting increased agricultural investment. For example, in 2009 the Ethiopian government set aside 1.6 million hectares (4 million acres) that it could offer up for agribusiness investment, with the option to extend it again to 2.7 million hectares (6.7 million acres) (Reuters, 2009, cited in Cotula, 2011).

The second category, government-enforced regulation, accounts for those cases where national, provincial, or local governments protect local land rights and attempt to reduce adverse effects, at least to some extent. It is important to note that these protections need not be legal, although they often are. This regulation must involve some degree of enforcement; the mere existence of laws governing land grab is insufficient. Moreover, the regulation may come from any level of government. Local officials in particular often fail to act in the community's best interests when allocating land resources (Anseeuw et al., 2012). In Ghana most of the investment appears to occur on customary land, not state-owned land, with investors "exploit[ing] the ignorance" of the councils of elders who manage customary land at the local level (German, Schoneveld, \& Mwangi, 2011, p. 20. In contrast, the national government does not seem to engage in negotiations with investors and has not used its right to eminent domain in order to reallocate land to investors. 
Moreover, government regulation may emerge out of practice, rather than through explicit policymaking, and may manifest itself in the absence of land grab. For example, in a study on Vietnamese tree plantations, Sikor (2012) highlights how government agencies have accommodated local land rights and set up a bank to increase access to rural finance. Partly as a result of these government practices, rural households continue to own and operate many of the country's tree plantations, while transnational corporations have struggled and largely failed to take control.

The final category is civil society regulation. In cases where the government has failed to regulate international acquisitions, and especially in the case where it fails to enforce laws already on the books, civil society organizations may rise to fill the gap, articulating their demands through protests and occupations. This category requires that civil society organizations be sufficiently strong not only to mobilize local communities, but also to force governments and/or the companies themselves to reevaluate the terms of the land transfer.

Civil society regulation is often not purely domestic in nature, but instead linked, either formally or informally, to a transnational activist network. In some cases the organization itself may be transnational, such as the international movement of small farmers Via Campesina. Furthermore, such transnational movements may compete with or contradict each other in the positions they take vis-à-vis land investment, as illustrated by Borras, McMichael, and Scoones's analysis of $\mathrm{La}$ Via Campesina and the International Federation of Agricultural Producers (2010). Even relatively powerless domestic organizations may gain influence and legitimacy by positioning themselves in the context of larger social movements or by seeking out international allies who put pressure on the state from outside (Hertel, 2006; Keck \& Sikkink, 1998). Indeed, an Oakland Institute brief on South Sudan's largest land deal and the resulting media coverage helped to mobilize local communities against the deal, who successfully halted the project by appealing to the central government (Oakland Institute, 2011). Through engagement with transnational activist networks, civil society protests not only better ensure their own success, but can have a precipitating effect on social movements, either regionally or globally.

Although excluded for the time being, international regulation could be incorporated into this typology when and if it comes into existence. International Codes of Conduct, like the Principles for Responsible Agricultural Investment, jointly developed by UNCTAD, FAO, IFAD, and the World Bank, have been proposed as a way to protect local populations and govern the process of land deals in developing countries, all while allowing them to capitalize on foreign investment (Committee on World Food Security, 2013; FAO, IFAD, UNCTAD, and the World Bank Group, 2010; FAO, 2012; Foljanty \& Wagner, 2009; von Braun \& Meinzen-Dick, 2009). ${ }^{2}$ These principles are currently under consultation, but when they are finalized, a fourth column could be added to the typology. Such international regulation is distinct from the other categories in that third-party organizations or the investors themselves would likely be the ones to implement and enforce it. It is worth adding that this typology illustrates how a code of conduct is far from the only route to more "just" land deals. Regulation can come from a host of different actors and interactions, suggesting that the present focus on a code of conduct ignores other potential sources of regulation.

There is one more category of regulation that this typology omits: regulation by companies themselves. For various reasons, some investors attempt to self-regulate their projects in order to ensure that livelihoods and environments are preserved. In practice, this may be difficult, given the complexities of how governments define unused lands and what little or misconstrued information some investors may receive. Still, a variety of company commitment instruments do exist, with limited endorsement (Zwart \& Novib, 2011). Such voluntary regulation is exogenous to the typology because it will only apply to specific projects and/or companies and cannot be generalized to industries or countries. Without this

\footnotetext{
2 The premises behind a code of conduct, as well as the solutions promised, have been questioned and are far from universally accepted (Borras \& Franco, 2010b).
} 
predictive power, it is not a useful variable in the typology.

\section{Illustrative Cases}

In the following section, two illustrative cases of land acquisition help to depict the general characteristics of each type and reveal some of the difficulties in categorization. In each case, the renewed focus on investor-regulatory actor interactions raises unexplored normative, political, and economic questions.

\section{A. Paper Industry in Brazil}

In land use typology: Mix between Types C and G (food/nonfood to nonfood)

In interactions typology: Type F (mixed investor, civil society regulation)

Land deals by the domestic and international paper industry in Brazil's Bahía region demonstrate how civil society organizations may step in when the government fails to respect de facto land rights and, in so doing, change the outcome of the land deals themselves. I will focus on the Veracel plantation case, which belongs to Type $\mathrm{F}$ in the actor interactions typology, representing domestic investors with foreign capital and a deal regulated by civil society organizations.

Veracel began as a Brazilian business conglomerate, but in 1997 a new company, Veracruz, was formed with Swedish Stora, which then merged with Finnish company Enso, of which 60 percent belongs to the state. In 2000, the conglomerate Odebrecht sold many of its shares to Aracruz (Kröger \& Nylund, 2011). This case thus epitomizes the complexities of categorizing investor type. Joint operations like Veracel more closely resemble their foreign counterparts in that they are at least partially financed by international funds. Yet with significant domestic input, they are better able to capitalize on local expertise and networks to navigate bureaucracy and strike deals with local officials and communities. As such, they can be considered a "mixed investor."

Tree plantations like Veracel are not new to Brazil's landscape, but in the last decade they have increasingly pushed into state lands, spurring pro- test movements by local activists (Kröger, 2012). In 2004 activists from Brazil's landless movement MST uprooted several hectares of commercially planted eucalyptus and staged an occupation of the land. Kröger (2011) notes that the government "response to the occupation and its results were swift" (p. 437. The government soon gave the MST 30,000 hectares (74,000 acres) in settlement promises and ordered Veracel to uproot an additional 47,000 hectares (116,000 acres). Slowing the Veracel project was only one of MST's many successes. Throughout the region, their protests have slowed or terminated several plantation expansion projects that would have infringed upon agricultural lands with varying degrees of cultivation (Kröger, 2011).

But, where is the Brazilian government in all of this? The Brazilian Land Reform Institute (INCRA) is weak and grossly underfunded (Kröger, 2011; Kröger \& Nylund, 2011; Wolford, 2010b). Moreover, roughly half of all land in Brazil is not registered with the agency (Reydon \& Fernandes, 2013). According to Wolford (2010b), INCRA's weak technical capacity and lack of resources have created an opportunity for MST and similar civil society organizations to dispute and shape the terms of Brazilian agrarian policies. Although INCRA's weakness may only partly explain the rise of civil society regulation (Kröger 2011), there is no doubt that MST has played a critical role in shaping and halting these land deals. Land expansions have occurred at slower rates, often with more just terms, or been cancelled altogether. In the Brazilian case, civil society regulation has emerged as an effective means of protecting local landowners and holding the government accountable for the legal protections it has been unable to provide.

Even nonviolent protests, such as those organized by MST, do run the risk of becoming violent and resulting in more harm than gains. In other cases of MST protest, police wearing full riot gear have broken up protestors' camps. Had the activists not removed roadblocks, the military may have intervened, with potentially violent consequences (Kröger, 2011). Since peaceful resolution of the problem is far from guaranteed, analysis of civil society regulation must take into account the 
cost-benefit scenarios inherent in citizens' activism.

This case sheds light on an underexplored puzzle in the comparative literature on land deals: the role of civil society organizations in preventing land deals. Type F (mixed investor, civil society regulation) is not an empty case, since civil society protests are not completely effective, but it may be that egregious land deals are much less common under this set of circumstances. Are civil society organizations more or less effective at regulating land deals when some of the investors or capital is domestic? In other words, how does investor identity shape the rise of and effectiveness of civil society regulation? By examining this case through the typological framework, we can begin to ask these more targeted comparative questions.

Moreover, this case touches upon the occurrence of land deals in relatively strong states. Weak governance is a common feature where land grabs occur, but they also occur in states with strong institutions. For example, Brazil has strong institutions on the whole, but INCRA is the worst funded and most understaffed agency among them (Wolford, 2010b). Future research would thus benefit from investigating two separate categories of land deals: those occurring in states with overall weak governance, and those occurring in countries with relatively weak land regulation vis-à-vis the entire state apparatus. The distinction between overall and relative institutional weakness is an important one, in part because it will likely have implications beyond the extent of government regulation. Based on the events of the attempted Veracel expansion, we might predict that civil society organizations in strong states will be dissatisfied with weak land regulation, have higher expectations for protection of their land rights, and possibly take upon themselves the responsibility to regulate land deals. In this manner, the typology's renewed focus on land regulation probes the assumption of weak governance and guides us to new research questions.

\section{B. Green Future Innovations Sugar Cane Ethanol in the Philippines}

In land use typology: Type B (food to biofuels)
In interactions typology: Type $\mathrm{G}$ (mixed investor, little to no protection)

Whereas the Brazilian case has seen effective regulation, the sugar cane ethanol industry in the Philippines has not. The contrasts between the two outcomes shed light on the importance of regulation and the potential of mixed investors to inhibit effective regulation by the government or even by civil society organizations. This case thus demonstrates the need to focus on investor's source of capital, thereby separating mixed investors from both their foreign and domestic counterparts.

In recent years, the Philippines has sought out international land investment, primarily for biofuels projects. The search for available "idle" lands is ubiquitous, with targeted food and energy investments in nearly every province nationwide. One example is the Green Future Innovations project in Isabela province, where a consortium backed by foreign and domestic capital has begun acquiring some of the 11,000 hectares $(27,000$ acres $)$ promised to the project by the Filipino government. Green Future Innovations has Taiwanese, Japanese, and American companies doing most of the processing for ethanol production, while the Filipino corporation is a "consolidator of land" (Borras, Franco, Carranza, \& Alano, 2011). It has become a special project of the president and is expected to become the country's largest producer of ethanol.

In the case of the Philippines, a handful of laws exist to regulate foreign investment, including the Republic Act 8179, which puts limits on foreign ownership of corporations and lands (Borras, Franco, et al., 2011). These limited regulations seem to do little to protect local populations. Instead, they encourage foreign firms that seek out partnerships with domestic capital, as occurred with Green Future Innovations. Although further investigation is necessary, this joint partnership seems to have strengthened the project's position in the country. In particular, the project seems to be centered in San Mariano for "no other reason...than it is the apparent pet project of the current mayor" (Franco, Carranza, \& Fernandez, 2011, "Preliminary findings," para. 4). Additionally, the domestic partners have close ties to some of 
the major players in tobacco, grains, and sugar in the Philippines. In other words, the domestic partnership has allowed the foreign investors to tap local networks and situate themselves within the complex and historical dynamics of elite control.

Moreover, this case demonstrates some of the social consequences of a government's failure to regulate sufficiently. The government's consistent overstatement of the availability of "idle" land has forced officials to go searching for new lands to hand over to the project. These "new" lands were often used for corn production by smallholders, and several officials have expressed concerns that the lease rate is too low and that people will lose lands that are rightfully theirs (Borras, Franco, et al., 2011). This problem is further exacerbated by a lack of formal land titling in the Philippines, putting the lands of local farmers at risk.

Intriguingly, civil society organizations have not risen to fill the gap in regulation, even though they successfully put an end to an earlier, 1.3 million hectare (3.2 million acre) deal with China for food exports (Borras, Franco, et al., 2011). Why did civil society organizations mobilize around the one project, but not around biofuels in Isabela? Is exporting foods uniquely troublesome, given that the Philippines is the world's largest rice importer? Is it a question of scale - the difference between 1.3 million hectares (3.2 million acres) and 11,000 hectares $(27,000$ acres)? Is there something more unpalatable about the Chinese as investors than a joint operation between Filipinos and foreigners? Why and when do researchers encounter "fear and/or silence" from local residents, as they did with the Green Future Innovations project (Franco, Carranza, \& Fernandez, 2011, "Preliminary findings," para. 4)?

Perhaps most importantly, the typology enables comparison across space and time, for example, between the Brazilian paper industry and the Filipino sugar cane industry. Why do we see civil society regulation in Brazil and not in the Philippines? Is it the result of the relative strength of civil society organizations in each country? Or is there something different about a joint venture (as in Brazil) and a domestic investor backed by foreign capital (as in the Philippines)? By focusing on the typology's two salient variables — investor type and extent of regulation - we are forced to examine an oft-understudied aspect of land deals, the bargaining process itself. In this way, these typologies lead us to the difficult questions about why land grab occurs and why given deals have the results they do. These typologies cannot answer such questions, but they can shift the debate away from a one-sided focus on the effects of land grab, encouraging more comparative analysis between existing and future case studies.

\section{Discussion}

In this analysis, I have pinpointed and examined three biases in existing typologies of land grab: (a) the disregard for capital flows and the large category of "mixed investors"; (b) the failure to account for speculative and nonproductive investments; and (c) the tendency to downplay or ignore how domestic actors help to decide land deals.

In order to counteract these biases, I have proposed two typologies that, working in conjunction, question why land deals occur where they do and how they change the land itself. I first amend the Hall (2011) typology to include nonproductive land uses, calling for better research on how speculation and conservation projects differ from agricultural or biofuels production in their effects on community dynamics and physical geography.

A second typology maps the interactions between different categories of foreign investors and domestic actors, ranging from civil society organizations to local leaders to national governments. This typology rejects the tendency to focus exclusively on investor nationality and proposes that future research instead examine capital flows as a driver of foreign investment. Moreover, this typology identifies a wide variety of mechanisms with the potential to foster effective regulation, a code of conduct being only one of many.

As a highly stylized model of the global land grab, these typologies will do little to explain variables exogenous to the model and cannot explain every facet of land grab. Although reality is always more complex and contradictory, the typologies' descriptive and predictive power lie in their simplicity. Typological analysis is no substitute for rigorous case studies, but rather should 
inform that analysis by illuminating which cases are representative of a more general pattern and which are genuinely anomalous.

Most importantly, by focusing on the investors and regulatory actors themselves, this analysis leads us to hitherto unanswered or undiscovered questions about the global land grab. This discussion explores, in turn, the economic, political, and normative implications of this shift in perspective. Although it is far from an exhaustive list, I hope to show some of the frictions with which future research might engage and how this new framework can be employed to expand and refocus the research agenda on land grab.

Perhaps the most important contribution of this paper will be its call for better analysis of investor types and the existence of purely speculative land deals. Up until now, very little analysis has been done on the investors themselves - who they are, what motivates them, and how they negotiate land deals. What portion of "domestic" investors rely exclusively on domestic funding? Given the growing financialization of agriculture (Fairbairn, 2013), can we better document the extent to which there exist purely speculative deals?

By bringing the state back into focus, this work also deepens questions of how recipient country political systems encourage, condone, or discourage large-scale land investments by foreign investors. As is often documented in case-study analysis, states play an active role in seeking out and competing for land investment, such as when the Rwandan government passed a law to bring all marshes under state control with the goal of attracting more intensive agriculture (Veldman \& Lankhorst, 2011). Other states, however, may passively allow investment to occur. At what level does government enforcement break down? It is not merely a question of enforcement of legal frameworks, but rather a complex web of political motivations, existing legal frameworks, institutional funding priorities, and the relative strength of institutions governing land grab.

Furthermore, I question the prevailing assumption that land deals in Latin America occur under strong institutional oversight. Under what conditions are the terms of land deals in so-called "stronger" states like Brazil and Argentina more or less favorable to rural populations and smallholder agriculture? Are civil society organizations better organized and more likely to engage in land conflicts in more powerful, wealthier states? Intraregional and interregional analysis is necessary to test how much institutional strength and the level of economic development affect the scope and gravity of land deals. Brazil is a particularly promising case study for future research because it is both a source of land investment in other countries, like Bolivia, and a site for land deals by other foreign companies (Liu et al., 2013).

Beyond the state, engaging with this typology has the potential to clarify the role of civil society organizations and social movements. When compared to mining industries, land deals for agriculture and biofuels seem to prompt fewer and less cohesive protest movements. Land deals do spark resistance, whether it is the mob in Uganda that killed an Indian man over proposed rainforest clearing or the protestors in Sierra Leone who blocked access to an investment site (Kugelman \& Levenstein, 2013). Still, protest is not the norm. ${ }^{3}$ Why have we not seen greater mobilization by peasant movements worldwide? Is it a function of the weakness of civil society organizations vis-à-vis investors and state? What are the conditions that enable effective civil society regulation — existing laws to which to appeal? Strong community support? Receptive media sources, as occurred with the Financial Times negative coverage of South Korean investments in Madagascar (Kugelman \& Levenstein, 2013)?

Moreover, by refocusing the discussion on the interactions between investors and domestic actors, I hope to call attention to the ways in which land deals are settled. Some have suggested that corruption and bureaucratic maneuvering are more effective routes to completing a land deal than formal legal and political processes. For example, Kenyan elites have illegally and/or irregularly accessed

\footnotetext{
${ }^{3}$ This seeming "absence" of protests may be partly, though not fully, explained by underreporting of protests, especially when compared to the reported number of land deals. Some protests may be deemed insignificant or they may go unnoticed because they occur in hard-to-reach, remote locations (Borras \& Franco, 2013).
} 
public lands for personal gain, despite the fact that they were earmarked for the public interest (O'Brien, 2011). In another case, a Kenyan city commission served as a broker and secured public use land for a foreign company (Klopp, 2000, cited in O'Brien, 2011). Globally, how often and under what conditions do foreign companies use elites to secure land, just as has been documented in Kenya? Corruption is likely to be a significant factor at all levels of government and all types of agricultural investments.

Finally, when we examine and discuss landgrab regulation, as in this typology, we must engage with the question of justice in land grab. Defining — if only abstractly — what a just land deal looks like will help us to gauge how other deals measure up. The biases outlined herein provide useful insight into how future research might proceed. They bring into focus a host of ethical questions, only some of which have come to the fore in the debate over agricultural investment. These include: (a) What are the state's responsibilities vis-à-vis local populations? (b) In the face of food security issues, is imposing environmental conservation on cultivated lands - or forests used for harvesting and game - morally acceptable? (c) To what extent are investors responsible for investigating and avoiding the ill effects caused by their projects? (d) Are some categories of the typologies (for example, food to nonproduction) more problematic than others?

Beyond broadening the scholarly research agenda, however, this paper may also facilitate improved policymaking around the global land grab. In particular, this model helps us to identify high-risk areas for land grab: where regulation is weak, where speculative investment is rampant, or where lands were previously used almost exclusively for food production. By taking the project as its unit of analysis, it also helps us to predict, albeit broadly, the causes and effects of unknown cases by drawing comparisons to similar projects of the same type. Perhaps most importantly, this typology opens new avenues for just land distributions by focusing on the various routes to effective investment regulation. Rather than envisioning a world where a growing resource problem will not necessitate some foreign investment, I accept this fact to be true for the foreseeable future. Therefore, the policymaker's challenge is to determine what types of regulation are most effective and how the international or domestic system can foment organic regulation processes in a frenzied investment environment. This task demands the attention of researchers and policymakers alike, and it requires acceptance of the need for increased cultivation and/or improved land yields if future hunger and food insecurity are to be avoided. I only hope that we are able to move past polemical debates about "land grab" and focus on the task ahead of us, for it is an arduous one.

\section{Acknowledgments}

I am grateful for research support from the Leitner Program in International and Comparative Political Economy, the Evalyn Elizabeth Cook Richter Fellowship, and the Department of Ethics, Politics, and Economics at Yale University. I would also like to express my deep gratitude to Elisabeth Wood, whose guidance and input were invaluable throughout this entire project. Finally, I thank the many people who commented on earlier versions of the paper, particularly James Scott, Robert Blair, and Jennifer Downing.

\section{References}

Anseeuw, W., Wily, L. A., Cotula, L., \& Taylor, M. (2011). Land rights and the rush for land: Findings of the Global Commercial Pressures on Land Research Project.

Rome: International Land Coalition. Retrieved from http://www.landcoalition.org/sites/default/ files/publication/1205/ILC\%20GSR\%20report_ ENG.pdf

Anseeuw, W., Boche, M., Breu, T., Giger, M., Lay, J., Messerli, P., \& Nolte, K. (2012). Transnational land deals for agriculture in the global South: Analytical report based on the Land Matrix Database. Bern/ Montpellier/Hamburg: Centre for Development and Environment (CDE)/French Agricultural Research Centre for International Development (CIRAD)/German Institute of Global and Area Studies (GIGA). Retrieved from http://www.landcoalition.org/publications/ transnational-land-deals-agriculture-global-south 
Baquero, F. S., \& Gómez, S. (Eds.). (2012). Dinámicas del mercado de la tierra en América Latina y el Caribe: Concentración y extranjerización. Rome: Food and Agriculture Organization of the United Nations [FAO]. Retrieved from http://www.rlc.fao.org/en/ publications/dinamicas-mercado-tierra/

Behrman, J., Meinzen-Dick, R., \& Quisumbing, A. (2011). The gender implications of large-scale land deals (IFPRI Discussion Paper 01056). Washington, D.C.: International Food Policy Research Institute. Retrieved from http://www.ifpri.org/publication/ gender-implications-large-scale-land-deals

Benjaminsen, T. A., \& Bryceson, I. (2012). Conservation, green/blue grabbing and accumulation by dispossession in Tanzania. Journal of Peasant Studies, 39(2), 335-355.

http://dx.doi.org/10.1080/03066150.2012.667405

Blumenthal, G. R. (2013). Investors' perspectives. In M. Kugelman \& S. L. Levenstein (Eds.), The global farms race: Land grabs, agricultural investment, and the scramble for food security (pp. 99-112). Washington, D.C.: Island Press.

Borras, S. M., Jr., \& Franco, J. (2010a). Towards a broader view of the politics of global land grab: Rethinking land issues, reframing resistance (Initiatives in Critical Agrarian Studies [ICAS] Working Paper Series No. 001). The Hague: Initiatives in Critical Agrarian Studies, Land Deal Politics Initiative, and Transnational Institute. Available from http://www.tni.org/paper/towards-broader-viewpolitics-global-land-grabbing

Borras, S., Jr., \& Franco, J. (2010b). From threat to opportunity? Problems with the idea of a "code of conduct" for land grabbing. Yale Human Rights \& Development Law Journal, 13, 507-523.

Borras, S. M., Jr., \& Franco, J. C. (2013). Global land grabbing and political reactions 'from below.' Third World Quarterly, 34(9), 1723-1747. http://dx.doi.org/10.1080/01436597.2013.843845

Borras, S. M., Jr., Franco, J. C., Carranza, D., \& Alano, M. L. (2011, April). The fundamentally flawed 'marginal lands' narrative: Insights from the Philippines. Paper presented at the International Conference on Global Land Grabbing, University of Sussex, Sussex, UK.

Borras, S. M., Jr., Franco, J. C., Gómez, S., Kay, C., \& Spoor, M. (2012). Land grabbing in Latin America and the Caribbean. Journal of Peasant Studies, 39(3-4),
845-872. http://dx.doi.org/10.1080/03066150. 2012.679931

Borras, S. M., Jr., Hall, R., Scoones, I., White, B., \& Wolford, W. (2011). Towards a better understanding of global land grabbing: An editorial introduction. The Journal of Peasant Studies, 38(2), 209-216. http://dx.doi.org/10.1080/03066150.2011.559005

Borras, S. M., Jr., McMichael, P., \& Scoones, I. (2010). The politics of biofuels, land, and agrarian change: Editors' introduction. Journal of Peasant Studies, 37(4), 575-592. http://dx.doi.org/10.1080/03066150.2010.512448

Clancy, J. S., Lovett, J. C., \& Marin, V. (2011, April). Biofuels and land appropriation in Colombia: do biofuels national Policies fuel land grabs? Paper presented at the International Conference on Global Land Grabbing, University of Sussex, Sussex, UK.

Committee on World Food Security. (2013). Principles for responsible agricultural investment (RAI) in the context of food security and nutrition: Zero Draft. Available from http://www.fao.org/fileadmin/ templates/cfs/Docs1314/rai/CFS rai Zero Draft 01 August 2013 EN.pdf

Cotula, L. (2011). The outlook on farmland acquisitions. Rome: International Land Coalition.

Cotula, L. (2012). The international political economy of the global land rush: A critical appraisal of trends, scale, geography and drivers. Journal of Peasant Studies, 39(3-4), 649-680. http://dx.doi.org/10.1080/03066150.2012.674940

Cotula, L., Vermeulen, S., Leonard, R., \& Keeley, J. (2009). Land grab or development opportunity? Agricultural investments and international land deals in Africa. London: IIED.

Daley, E. (2011). Gendered impacts of commercial pressures on land. International Land Coalition.

De Schutter, O. (2010). How not to think of landgrabbing: Three critiques of large-scale investments in farmland. Journal of Peasant Studies, 38(2), 249_ 279. http://dx.doi.org/10.1080/03066150.2011.559008

Deininger, K. (2003). Land policies for growth and poverty reduction. Washington, D.C.: The World Bank. http://documents.worldbank.org/curated/en/2003 /06/2457830/land-policies-growth-povertyreduction 
Deininger, K., \& Byerlee, D. (2011a). The rise of large farms in land abundant countries: Do they have a future? (World Bank Policy Research Working Paper 5588). Washington, D.C.: The World Bank. Retrieved from http://elibrary.worldbank.org/doi/book/ 10.1596/1813-9450-5588

Deininger, K., \& Byerlee, D. (2011b). Rising global interest in farmland: Can it yield sustainable and equitable benefits? Washington, D.C.: World Bank.

Fairbairn, M. (2013, September). "Like gold with yield": Evolving intersections between farmland and finance. Paper presented at the International Conference on Food Sovereignty: A Critical Dialogue, Yale University, New Haven, Connecticut. Retrieved from http://www.yale.edu/agrarianstudies/ foodsovereignty/papers.html

Fairhead, J., Leach, M., \& Scoones, I. (2012). Green grabbing: A new appropriation of nature? Journal of Peasant Studies, 39(2), 237-261.

http://dx.doi.org/10.1080/03066150.2012.671770

FAO, International Fund for Agricultural Development [IFAD], United Nations Conference on Trade and Development [UNCTAD], and the World Bank Group. (2010). Principles for responsible agricultural investment that respects rights, livelihoods, and resources: Synoptic version (a discussion note to contribute to an ongoing global dialogue). Retrieved from http://unctad.org/en/Pages/DIAE/G-20/ PRAI.aspx

FAO. (2012). Voluntary guidelines on the responsible governance of tenure of land, fisheries, and forests in the context of national food security. Rome: Author. Retrieved from http://www.fao.org/nr/tenure/voluntaryguidelines/en/

Foljanty, K., \& Wagner, J. (Eds.). (2009). Development policy stance on the topic of land grabbing - The purchase and leasing of large areas of land in developing countries (BMZ Discourse Series No. 015). Bonn and Berlin: Federal Ministry for Economic Cooperation and Development. Retrieved from http://www.bmz.de

Franco, J., Carranza, D., \& Fernandez, J. (2011). New biofuel project in Isabela: Boon or bane for local people? Retrieved from the Transnational Institute's Agrarian Justice website: http://www.tni.org/ article/new-biofuel-project-isabela

Geary, K. (2012). "Our Land, Our Lives": Time out on the global land rush (Oxfam Briefing Note). Oxford: Oxfam International. Retrieved from
http://www.oxfam.org/en/grow/policy/\%E2\%80 $\% 98$ our-land-our-lives $\%$ E2\%80\%99

German, L., Schoneveld, G., \& Mwangi, E. (2011, April). Processes of large-scale land acquisition by investors: Case studies from sub-Saharan Africa. Paper presented at the International Conference on Global Land Grabbing, University of Sussex, Sussex, UK.

GRAIN. (2008). Seized: The 2008 landgrab for food and financial security. Retrieved from http://www.grain. org/article/archive/categories/14-reports

GRAIN. (2012). Land grab deals data set. Retrieved from http://www.grain.org/article/entries / 4479-grainreleases-data-set-with-over-400-global-land-grabs

Hall, R. (2011). Land grabbing in Southern Africa: The many faces of the investor rush. Review of African Political Economy, 38(128), 193-214. http://dx.doi.org/10.1080/03056244.2011.582753

Hertel, S. (2006). Unexpected power: Conflict and change among transnational activists. Ithaca, New York: Cornell University Press.

Hinshaw, D. (2011, April 14). The great African land rush. The Atlantic. Retrieved from http://www.theatlantic.com/

Kay, S., \& Franco, J. (2012). The global water grab: A primer. Amsterdam: Transnational Institute. Retrieved from http://www.tni.org/primer/globalwater-grab-primer

Keck, M. E., \& Sikkink, K. (1998). Activists beyond borders: Advocacy networks in international politics. Ithaca, New York: Cornell University Press.

Kelly, A. B. (2011). Conservation practice as primitive accumulation. Journal of Peasant Studies, 38(4), 683701. http://dx.doi.org/10.1080/03066150.2011.607695

Kröger, M. (2011). Promotion of contentious agency as a rewarding movement strategy: Evidence from the MST-paper industry conflicts in Brazil. Journal of Peasant Studies, 38(2), 435-458. http://dx.doi.org/10.1080/03066150.2011.559016

Kröger, M. (2012). The expansion of industrial tree plantations and dispossession in Brazil. Development and Change, 43(4), 947-973. http://dx.doi.org/ 10.1111/j.1467-7660.2012.01787.x

Kröger, M., \& Nylund, J.-E. (2011). The conflict over Veracel pulpwood plantations in Brazil Application of ethical analysis. Forest Policy and Economics, 14(1), 74-82. http://dx.doi.org/10.1016/i.forpol.2011.07.018 
Kugelman, M., \& Levenstein, S. L. (Eds.). (2013). The global farms race: Land grabs, agricultural investment, and the scramble for food security. Washington, D.C.: Island Press.

Land Matrix Project. (n.d.). Land Matrix: The online public database on land deals. Retrieved December 2012 from http://landportal.info/landmatrix

Li, T. M. (2009). To make live or let die? Rural dispossession and the protection of surplus populations. Antipode, 41(s1), 66-93. http://dx.doi.org/10.1111/j.14678330.2009.00717.x

Liu, P., Koroma, S., Arias, P., \& Hallam, D. (Eds.). (2013). Trends and impacts of foreign investment in developing country agriculture: Evidence from case studies. Rome: FAO. Retrieved from http://www.fao.org/ economic/est/publications/trends/en/

MacFarquhar, N. (2010, December 21). African farmers displaced as investors move in. New York Times. Retrieved from http://www.nytimes.com/

MacInnes, M. (2012, October). Corruption and largescale land acquisitions: An analysis of the role high level corruption plays in enabling elite capture of land. Paper presented at the International Conference on Global Land Grabbing II, Cornell University, Ithaca, New York. Retrieved from www.cornell-landproject.org/

Oakland Institute. (2011). Success at halting largest foreign land deal in South Sudan. Retrieved from http://www.oaklandinstitute.org/success-haltinglargest-foreign-land-deal-south-sudan

O'Brien, E. (2011). Irregular and illegal land acquisition by Kenya's elites: Trends, processes, and impacts of Kenya's land-grabbing phenomenon. Rome: International Land Coalition. Retrieved from http://www.landcoalition.org/

Reydon, B. P., \& Fernandes, V. B. (2013). Regional perspectives: Latin America. In M. Kugelman \& S. L. Levenstein (Eds.), The global farms race: Land grabs, agricultural investment, and the scramble for food security (pp. 153-168). Washington, D.C.: Island Press.

Scoones, I., Chaumba, J., Mavedzenge, B., \& Wolmer, W. (2012). The new politics of Zimbabwe's lowveld: Struggles over land at the margins. African Affairs, 111(445), 527-550. http://dx.doi.org/10.1093/afraf/ads057

Sikor, T. (2012). Tree plantations, politics of possession and the absence of land grabs in Vietnam. Journal of
Peasant Studies, 39(3-4), 1077-1101. http://dx.doi.org/10.1080/03066150.2012.674943

Veldman, M., \& Lankhorst, M. (2011). Socio-economic impact of commercial exploitation of Rwandan marshes: $A$ case study of sugar cane production in rural Kigali. Rome: International Land Coalition, CIRAD, and RCN Justice \& Démocratie. Retrieved from http://www.landcoalition.org/

Vermeulen, S., \& Cotula, L. (2010a). Over the heads of local people: Consultation, consent, and recompense in large-scale land deals for biofuels projects in Africa. Journal of Peasant Studies, 37(4), 899-916. http://dx.doi.org/10.1080/03066150.2010.512463

Vermeulen, S., \& Cotula, L. (2010b). Making the most of agricultural investment: A survey of business models that provide opportunities for smallholders. London/Rome/ Bern: International Institute for Environment and Development (IIED), FAO, IFAD, Swiss Agency for Development Cooperation (SDC). Retrieved from http://pubs.iied.org/12566IIED.html

Von Braun, J., \& Meinzen-Dick, R. S. (2009). 'Land grabbing” by foreign investors in developing countries: Risks and opportunities (IFPRI Policy Brief 13). Washington, D.C.: International Food Policy Research Institute (IFPRI). Retrieved from http://www.ifpri.org/

Wolford, W. (2010a, October). Contemporary land grabs in Latin America. Paper presented at the TNIICAS-

FIAN Side Event to the 13th Session of the FAO World Food Security Council, Rome. Retrieved from http://devsoc.cals.cornell.edu/research/ faculty-research-projects/wendy-wolford

Wolford, W. (2010b). Participatory democracy by default: Land reform, social movements and the state in Brazil. Journal of Peasant Studies, 37(1), 91-109. http://dx.doi.org/10.1080/03066150903498770

Woodhouse, P. (2012). New investment, old challenges. Land deals and the water constraint in African agriculture. Journal of Peasant Studies, 39(3-4), 777-794. http://dx.doi.org/10.1080/03066150.2012.660481

Woodhouse, P., \& Ganho, A. S. (2011, April). Is water the bidden agenda of agricultural land acquisition in subSabaran Africa? A paper presented at the Land Deal Politics Initiative (LDPI) International Conference on Land Grabbing, University of Sussex, Sussex, UK. Retrieved from http://www.iss.nl/ldpi 
Woods, K. (2013, September). The politics of the emerging agro-industrial complex in Asia's " final frontier": The war on food sovereignty in Burma. Paper presented at the International Conference on Food Sovereignty: A Critical Dialogue, Yale University, New Haven, Connecticut. Retrieved from http://www.yale.edu/ agrarianstudies/foodsovereignty/papers.html

Zoomers, A. (2010). Globalisation and the foreignisation of space: Seven processes driving the current global land grab. Journal of Peasant Studies, 37(2), 429-447.

http://dx.doi.org/10.1080/03066151003595325

Zwart, G., \& Novib, O. (2011). Company commitment instruments to safeguard the food/ land rights of people confronted with land use shifts (Policy Brief). Rome: International Land Coalition. Retrieved from http://www.landcoalition.org/ 